\title{
O DIREITO DO DOADOR DE MATERIAL GENÉTICO DE TER RECONHECIDA A FILIAÇÃO BIOLÓGICA, À LUZ DO PROVIMENTO № 52 DA CORREGEDORIA NACIONAL DE JUSTIÇA ${ }^{1}$
}

THE RIGHT OF THE DONOR OF GENETIC MATERIAL TO HAVE RECOGNIZED THE BIOLOGICAL AFFILIATION, IN LIGHT OF PROVISION N. 52 OF BRAZIL'S INTERNAL AFFAIRS OF JUSTICE

\author{
Mariane Paiva Norões \\ Antonio Jorge Pereira Júnior \\ Jéssica Ramos Saboia
}

\section{RESUMO}

Este artigo tem o escopo de verificar a possibilidade jurídica de o doador de material genético ter reconhecida a filiação biológica, a partir do Provimento no 52 da Corregedoria Nacional de Justiça, que vedou o anonimato do doador de gametas femininos e masculinos no Brasil. A metodologia utilizada foi a investigação do tipo documental-bibliográfica, com pesquisa pura de abordagem qualitativa, descritiva e exploratória quanto aos objetivos. A controvérsia gira em torno de uma aparente colisão entre os direitos fundamentais ao anonimato do doador de material genético e a identidade genética da pessoa concebida por reprodução humana assistida heteróloga.

Palavras-chaves: Anonimato do doador. Identidade genética. Reprodução humana assistida heteróloga.

\section{ABSTRACT}

This article has the scope to verify the legal possibility of the donor of genetic material to have recognized the biological affiliation, from the Provision N. 52 of Brazil's Internal Affairs of Justice, which closed the anonymity of the donor of male and female gametes in Brazil. The methodology used was documentalbibliographic research, with a pure qualitative, descriptive and exploratory 
approach to the objectives. The controversy centers around an apparent collision between fundamental rights to the donor's anonymity of genetic material and the genetic identity of the person conceived by heterologous assisted human reproduction.

Keywords: Donor anonymity. Genetic identity. Heterologous assisted human reproduction.

\section{INTRODUÇÃO}

Os avanços nas ciências médicas e nas tecnologias garantem o livre exercício de direitos fundamentais e o desenvolvimento humano e social. Porém, também favorecem o surgimento de novas modalidades de conflitos, os quais devem ser objeto de estudo da ciência jurídica.

Nesta perspectiva, a reprodução humana assistida surgiu para solucionar problemas de procriação natural humana. A procriação artificial pode ser realizada de três formas: (1) com material genético do casal; (2) com o gameta de um dos membros do casal e o do doador; ou (3) com material genético de doadores. Nos casos que envolvem doadores de gametas feminino e masculino, o sistema jurídico brasileiro garante o direito ao anonimato tanto do doador quanto do receptor do material genético, conforme os artigos $2^{\circ}$ e $4^{\circ}$ da Resolução no 2.121/2015 do Conselho Federal de Medicina.

No entanto, em 14 de março de 2016, a Corregedoria Nacional de Justiça, sob comando da Ministra Nancy Andrighi, editou o Provimento $\mathrm{n}-52^{2}$, pelo qual se vedava o anonimato do doador de material genético no Brasil. 0 referido Provimento orienta os Cartórios de Registro Civil a constarem os dados dos genitores biológico na certidão de nascimento da pessoa concebida por reprodução assistida.

Embora o Provimento obrigue, para o ato de registro civil, a apresentação de documentos dos ascendentes biológicos, este fato não importa no reconhecimento de vínculo de parentesco (paternidade-filiação) e dos respectivos efeitos jurídicos entre doador (ou doadora) e a pessoa gerada por seu material genético. Dessa forma, o CNJ reconheceu e normatizou a posição já fixada pelo Supremo Tribunal de Federal no sentido 
de que a paternidade/maternidade intencionada ("socioafetiva") pode sobrepor-se à biológica ${ }^{3}$.

O problema é posto quando o doador do sêmen ou a doadora do óvulo, conhecendo a prole - neste caso, em razão do fim do anonimato do receptor do material genético -, requer judicialmente o reconhecimento da filiação biológica. Esta questão já foi tema de um filme intitulado "Minhas mães e meu pai", lançado em 12 de novembro de 2010, sob a direção de Lisa Cholodenko ${ }^{4}$. Neste filme, o doador de sêmen - solteiro e sem filhos - conhece dois irmãos adolescentes gerados por seu material genético. Os encontros entre eles se intensificam, a ponto de o genitor considerar-se pai dos adolescentes e estes seus filhos. Diante deste fato, objetiva-se, no presente artigo, analisar a possibilidade jurídica do doador de material genético requerer o reconhecimento espontâneo dos filhos e seus efeitos jurídicos.

A metodologia de pesquisa, quanto à abordagem ou à natureza do estudo, é do tipo bibliográfico e documental, uma vez que a investigação foi realizada com base em livros, artigos científicos de periódicos nacionais, legislação brasileira, jurisprudência do Supremo Tribunal Federal - palavra-chave "identidade genética" - e jurisprudência do Superior Tribunal de Justiça - palavra-chave "verdade biológica". Por fim, quanto à finalidade, a pesquisa é descritiva e exploratória, porque busca expor os métodos de reprodução humana assistida, as relações de parentesco, filiação e reconhecimento voluntário dos filhos, à luz da legislação brasileira, e investigar a posição doutrinária e jurisprudencial acerca da ponderação entre o direito ao anonimato do doador e do receptor de material genético e direito ao conhecimento das origens genéticas.

Portanto, o trabalho demonstra ser relevante, haja vista a interdisciplinaridade e a atualidade do tema estudado. Faz-se necessário estudar as consequências jurídicas advindas dos avanços nas ciências médicas e, consequentemente, analisar a ponderação entre o direito ao anonimato do receptor e do doador de material genético e do direito ao conhecimento da origem genética, em face do melhor interesse da prole. 


\section{REPRODUÇÃO HUMANA ASSISTIDA E A PRESUNÇÃO DE FILIAÇÃO}

A reprodução humana assistida busca atender aos anseios de casais inférteis, e mulheres e homens solteiros que desejam ter filhos. Neste sentido, o art. 1ํㅡ, Seção 1, da Resolução n. 2.121/15 do Conselho Federal de Medicina, afirma: "As técnicas de reprodução assistida (RA) têm o papel de auxiliar a resolução dos problemas de reprodução humana, facilitando o processo de procriação".

Partindo-se dessa pré-compreensão do papel da reprodução assistida, passa-se à sua definição. Guilherme Calmon Nogueira Gama (2003) define reprodução assistida como um conjunto de atos médicos para unir, artificialmente, os gametas feminino (óvulo) e masculino (espermatozoide), seja dentro do próprio corpo da mulher, chamando essa técnica de fertilização in vivo, ou, seja fora dele, numa proveta, denominando essa técnica de fertilização in vitro, cujo embrião, produto da fertilização, será, posteriormente, transferido para o útero da mulher, a fim de ser gestado.

Desta feita, as técnicas de reprodução humana assistida podem ser classificadas em: intracorpóreas ou extracorpóreas. As técnicas intracorpóreas são chamadas de inseminação artificial ou fertilização in vivo e consistem em inserir o espermatozoide no corpo da mulher por meio de uma transferência feita artificialmente, possibilitando a fecundação dentro do corpo materno. Já as técnicas extracorpóreas são chamadas de fertilização in vitro, e traduzem-se na manipulação do óvulo e do espermatozoide em um tubo de ensaio ou proveta, sendo, o embrião produzido fora do corpo, posteriormente, introduzido no útero da mulher (SOUZA, 2010).

Há vários métodos de procriação humana assistida, porém, neste artigo, serão analisados somente os mais conhecidos, sendo eles: GIFT (Ghameta Intra Fallopian Transfer), ICSI (Intra Cytoplasmic Sperm Injection), ZIFT (Zygote Intrafallopian Transfer) e FITE (Fertilização in vitro com transferência de embriões).

O primeiro deles é o método GIFT (Ghameta Intra Fallopian Transfer), que consiste na transferência dos gametas para dentro da trompa. Maria Helena Diniz (2006, p. 552) explica que o método GIFT refere-se 
à fecundação in vivo, ou seja, "[...] à inoculação do sêmen na mulher, sem que haja qualquer manipulação externa de óvulo ou de embrião". Ademais, Maria de Fátima Freire de Sá e Bruno Torquato de Oliveira Naves (2009) esclarecem que o método GIFT é usado em mulheres com infertilidade sem causa determinada, ou aparente, ou, ainda, em razão da presença de leve endometriose.

Outra técnica de reprodução assistida é a injeção intracitoplasmática de espermatozoide, denominada ICSI (Intra Cytoplasmic Sperm Injection), em que "o espermatozoide é introduzido diretamente no óvulo por meio de uma agulha. Esta técnica também é conhecida como micromanipulação do óvulo" (NAVES; SÁ, 2009, p. 111).

0 terceiro método é o ZIFT (Zygote Intrafallopian Transfer), que é a transferência do zigoto para dentro da trompa. Essa técnica consiste na retirada do óvulo da mulher para fecundá-lo na proveta, com sêmen do marido ou de outro homem, para depois introduzir o zigoto na trompa da mulher ou na de outra. Dentro da trompa, as células passarão a multiplicar-se e, em seguida, o embrião em formação caminhará em direção ao útero. (DINIZ, 2006; OLMOS, 2003)

Finalmente, o FITE (fertilização in vitro com transferência de embriões) é um método de reprodução humana assistida, através da qual se dá a fecundação do óvulo também na proveta, ou seja, os gametas masculino e feminino são previamente recolhidos e colocados em contato in vitro, e, em seguida, o embrião resultante é colocado no útero da mulher (NEVES; SÁ, 2009).

Acrescente-se que tanto a fertilização in vivo, quanto a fecundação in vitro, podem ser homóloga ou heteróloga. A fecundação é homóloga quando feita com os componentes genéticos advindos do casal, e a fecundação é heteróloga, se for feita com material fertilizante de terceiro, por exemplo, sêmen do marido e óvulo de outra mulher, ou sêmen de terceiro e óvulo da esposa ou sêmen e óvulo de outras pessoas, cujo embrião poderá ser implantado no útero da esposa ou de terceira pessoa (DINIZ, 2006).

O Código Civil de 2002 prevê a reprodução artificial homóloga e a heteróloga em uma única oportunidade, no seu art.1.597, quando trata da presunção de filiação na constância do casamento. Transcreve-se o art. 1.597, CC/2002: 
Art. 1.597. Presumem-se concebidos na constância do casamento os filhos: I - nascidos cento e oitenta dias, pelo menos, depois de estabelecida a convivência conjugal;

II - nascidos nos trezentos dias subsequentes à dissolução da sociedade conjugal, por morte, separação judicial, nulidade e anulação do casamento; III - havidos por fecundação artificial homóloga, mesmo que falecido o marido;

IV - havidos, a qualquer tempo, quando se tratar de embriões excedentários, decorrentes de concepção artificial homóloga;

V - havidos por inseminação artificial heteróloga, desde que tenha prévia autorização do marido.

Interessam aqui os incisos III, IV e V, do art. 1.597, CC/2002. Os incisos III e IV preveem que os filhos advindos de inseminação artificial homóloga e os embriões excedentários, decorrentes de concepção artificial homóloga, presumem-se concebidos na constância do casamento. Por outro lado, o inciso $\mathrm{V}$ estabelece que os filhos oriundos de inseminação artificial heteróloga, presumem-se concebidos na constância do casamento, se o marido concordar previamente com a inseminação artificial.

Neste diapasão, Maria de Fátima Freire de Sá e Bruno Torquarto de Oliveira Naves (2009, p. 114) asseveram que no caso da inseminação artificial heteróloga, onde se utiliza material de genético (óvulo e/ou esperma) de terceiro, "a filiação é garantida pela assinatura do 'Termo de Consentimento Livre e Esclarecido', que define a paternidade, impondo a responsabilidade pela criação, assistência e educação dos filhos, por conseguinte, o múnus da autoridade parental".

Ademais, a Resolução n. 2.121/15, do Conselho Federal de Medicina, em seu art. 4ํㅡㄹ, Seção 1, exige o consentimento livre e informado de todos os pacientes que irão se submeter às técnicas de reprodução assistida homóloga e heteróloga.

Ressalte-se que todas as ponderações que forem feitas relativamente ao casamento são aplicadas à união estável, porque desde a promulgação da Constituição Federal de 1988, as entidades familiares não fundadas no casamento ${ }^{5}$ também são dignas de especial proteção do Estado. Sendo assim, os companheiros igualmente têm acesso à reprodução assistida e, como no casamento, a presunção de filho concebido por procriação assis- 
tida heteróloga na constância da união estável depende da anuência do companheiro, demonstrando que a paternidade foi desejada e não imposta.

No plano jurisprudencial, o Supremo Tribunal Federal, no julgamento da ADI n. 3.510, em 29 de maio de 2008, entendeu que a opção do casal por um processo de reprodução humana assistida, em especial, por um processo in vitro de fecundação artificial de óvulos, é direito público subjetivo à liberdade ou à autonomia privada, previsto no preâmbulo da Constituição Federal e em seu art. 5ํㅜ , bem como direito ao planejamento familiar, fundado no princípio pouco elucidativo da "dignidade da pessoa humana" e no princípio da paternidade responsável, segundo entendimento extraído do $§ 7^{\circ}$, do art. 226, da Constituição Federal ${ }^{6}$.

Todavia, Claudia Regina Magalhães Loureiro (2009) e Maria Helena Diniz (2006) alertam para alguns problemas jurídicos e, até mesmo, morais advindos da fertilização artificial heteróloga, quais sejam: (1) o anonimato do doador de material genético violar o direito de identidade genética da pessoa; (2) a possibilidade de incesto, por meio da união dos filhos de mesmo doador, ou de filha do doador com ele mesmo, ou do filho da doadora com ela mesma; e (3) o doador do sêmen ou a doadora do óvulo, ao sair do anonimato e conhecer a prole, pretender reclamar judicialmente sua paternidade ou maternidade, reconhecendo como seu o filho biológico, sob o fundamento legal dos arts. $1.607^{7}$ e 1.609 , IV, Código Civil ${ }^{8}$.

Neste último caso, qual solução seria possível: negar a pretensão do doador, pois quem faz doação de sêmen deverá aceitar que o filho não é seu institucionalmente, mas qual a garantia legal de que esse pedido do doador será declarado improcedente em juízo? Ou, reconhecer a filiação biológica e atribuir-lhe todos os deveres jurídicos que a legislação civilista impõe?

Passa-se, então, no tópico seguinte a uma análise histórica, principiológica, doutrinária e jurisprudencial sobre os direitos subjetivos ao anonimato do doador e do receptor de material genético e ao conhecimento da origem genética, para, nos tópicos seguintes, verificar a possibilidade ou não de ser reconhecida a paternidade/maternidade do doador de material genético, e, em caso positivo, quais as suas implicações no Direito de Família. 


\section{ANONIMATO DO DOADOR E DO RECEPTOR DE MATERIAL GENÉTICO VERSUS CONHECIMENTO DA ORIGEM GENÉTICA}

Em face da dificuldade e, até mesmo, impossibilidade de se exercer controle efetivo sobre as consequências das ciências médicas em suas mais amplas dimensões espaço-temporais, demonstra-se relevante traçar e investigar os limites entre o direito ao anonimato do receptor e do doador de material genético e o direito ao conhecimento da origem genética, bem assim do doador requerer judicialmente o reconhecimento da filiação biológica, em face do melhor interesse da prole. Segundo a teoria alexyana, deve-se fazer uso da lei de colisão nos casos concretos, analisando qual direito deve prevalecer, haja vista que "as normas de direito fundamental são, não raro, caracterizadas como 'princípios."” (ALEXY, 2008, p. 86).

Thomas Bustamante (2010, p. 606) afirma que "uma colisão entre princípios constitucionais, principalmente nos casos em que estes têm igual peso abstrato ou importância, só pode ser resolvida pelo estabelecimento de certas relações de prioridade condicionada entre os princípios colidentes". A tarefa de estabelecimento das relações prioritárias cabe à ponderação, decorrente da lei de colisão.

A referida teoria está inserida em um contexto pós-segunda guerra mundial, quando houve quem sinalizasse que o Estado de Direito mostrou-se insuficiente para proteger a coletividade dos caprichos da Administração (MORAES, 2010), surgindo, a partir daí, a necessidade de reforçar os direitos, através da constitucionalização dos direitos fundamentais (ZAGREBELSKY, 2011), bem como reafirmar o primado da pessoa e das relações existenciais (PERLINGIERI, 2002), em detrimento das relações patrimoniais, e, por fim, a necessidade de fortalecer o Poder Judiciário e as Cortes Constitucionais em face de arbitrariedade do legislador ordinário e dos gestores. Isso propiciou o avanço técnico de construção de normas que possibilitaram a maior abertura do sistema, mediante conceitos jurídicos indeterminados, cláusulas gerais e princípios. As constituições entraram no mesmo clima.

Por conseguinte, esses acontecimentos incrementaram o Estado Constitucional. Tem-se, desde a segunda metade do século XX, a Cons- 
tituição a desempenhar o maior papel material nos sistemas jurídicos, incorporando-se o "valor pessoa" como norma fundante para os diversos ramos do direito, a partir do ápice normativo (PERLINGIERI, 2002).

Nesta lógica da denominada "repersonalização do Direito Civil", defendem alguns autores que as situações existenciais se sobrepõem às patrimoniais (TEPEDINO, 2009). José de Oliveira Ascensão (2010, p. 19) distingue as situações existenciais das situações patrimoniais: "As situações jurídicas pessoais são aquelas em que há prevalente aspecto ético, e as patrimoniais aquelas cuja essência é compatível com a redução a um valor pecuniário". Assim, as relações existenciais seriam aquelas intransmissíveis, enquanto as patrimoniais o seriam aquelas transmissíveis.

O Supremo Tribunal Federal parece coadunar com esse entendimento. Em 15 de dezembro de 2011, no julgamento do Recurso Extraordinário n. 363889/DF ${ }^{9}$, o Ministro Relator Dias Toffoli considerou que a coisa julgada não poderia prevalecer sobre o direito de o indivíduo conhecer a sua origem genética, visto que, o conhecimento da verdade sobre sua origem biológica é direito personalíssimo de todo ser humano ${ }^{10}$.

No mesmo sentido, o Superior Tribunal de Justiça, em 17 de maio de 2007, na decisão do Recurso Especial n. 833712/RS ${ }^{11}$, reconheceu o direito da investigante ao conhecimento da origem genética. A Ministra relatora Nancy Andrighi defendeu o direito da investigante ao acesso à sua verdade biológica, sob o fundamento de que "o estado de filiação constitui um direito personalíssimo, indisponível e imprescritível, que pode ser exercido sem qualquer restrição, em face dos pais ou seus herdeiros", e acrescentou que o conhecimento da verdade biológica está no bojo do princípio da "dignidade da pessoa humana", estabelecido no art. 1ํ, inc. III, da Constituição Federal de 1988.

Apesar desses casos de investigação de maternidade e paternidade, analisados na jurisprudência, não decorrerem da reprodução humana assistida heteróloga, há quem defenda que as pessoas advindas dessa modalidade de procriação possuem o direito ao conhecimento da sua origem genética (MORAES, 2010) e o doador teria o direito ao reconhecimento da filiação (PERLINGIERI, 2002).

Maria Celina Bodin de Moraes (2010, p. 103) se posiciona a favor do direito ao conhecimento à origem genética, afirmando assim que "o 
anonimato do doador de sêmen, na inseminação artificial heteróloga não compactua com a ordem constitucional da prevalência das situações existenciais", em razão do direito do filho ter acesso à sua origem genética, aspecto que compõe a essência de sua identificação.

Pietro Perlingieri (2002, p.177) também reconhece ao menor o direito de conhecer as próprias origens, mas não somente a genética, como também as culturais e sociais, em detrimento do anonimato do doador de sêmen, e isso "significa não apenas evitar o incesto, possibilitar a aplicação da proibição de núpcias entre parentes, mas, responsavelmente, estabelecer uma relação entre titular do patrimônio genético e quem nasce". Além disso, este autor inova na matéria, ao apresentar dois casos em que se poderia reconhecer a paternidade do doador de sêmen. 0 primeiro deles é o caso da mulher solteira se submeter a uma inseminação artificial com o sêmen de um doador e este, em um segundo momento, no interesse do menor, ao conhecer o fruto da reprodução assistida heteróloga, requerer o reconhecimento da paternidade. 0 segundo é o caso do pai registral morrer e o doador poder assumir algumas responsabilidades do tipo educativo em relação ao filho.

Claudia Regina Magalhães Loureiro (2009), moderadamente, apoia o direito de a pessoa conhecer a sua origem genética, devendo os bancos de material genético revelar à pessoa os antecedentes genéticos do doador sem, contudo, revelar a identidade civil do doador, em observância à exigência do sigilo profissional.

Antônio Chaves (1994) também é favor do anonimato da identidade civil do doador de sêmen, sustentando que os bancos de sêmen devem ocultar a identificação dos doadores do material genético que normalmente é empregado nas técnicas de reprodução assistida heteróloga e, com isso, evitariam o direito à investigação de paternidade, à reivindicação de alimentos e de herança. Maria Celina Bodin de Moraes (2010, p. 103) critica esse entendimento, afirmando que "a visão dos que sustentam o anonimato parece estar deformada pelo longo do tempo em que o direito civil cuidava unicamente de direitos subjetivos de matriz patrimonial".

Vale ressaltar que o sistema jurídico brasileiro, de acordo com os arts. $2^{\circ}$ e $4^{\circ}$ a Resolução n. 2.121/2015 do Conselho Federal de Medi- 
cina, nos casos que envolvem doadores de gametas, garante o direito ao anonimato tanto do doador quanto do receptor de material genético:

2 - Os doadores não devem conhecer a identidade dos receptores e vice-versa. [...]

4 - Será mantido, obrigatoriamente, o sigilo sobre a identidade dos doadores de gametas e embriões, como dos receptores. Em situações especiais, informações sobre os doadores por motivação médica, podem ser fornecidas exclusivamente para médicos, resguardando-se a identidade civil do(a) doador(a)".

Nesse contexto, a controvérsia gira em torno da ponderação entre o direito ao anonimato do receptor e do doador de material genético e do direito ao conhecimento da origem genética, bem assim do doador requerer judicialmente o reconhecimento da filiação biológica, em face do melhor interesse da prole. Para resolver essa tensão, deve-se analisar o caso concreto, utilizando a teoria de Robert Alexy, para fazer um sopesamento entre os princípios colidentes.

Com efeito, a doutrina diverge em relação à proteção do direito ao anonimato do doador de material genético. Já a jurisprudência do STF e STJ protege e garante o direito de qualquer pessoa conhecer a sua origem genética, porque se trata de uma situação existencial. Ocorre que outros direitos podem advir do conhecimento da identidade genética, como o já abordado direito do doador de material genético de ter reconhecida a filiação biológica. Sob esta perspectiva, passa-se, no tópico seguinte à analise da relação de parentesco e filiação no Brasil.

\section{RELAÇÃO DE PARENTESCO E FILIAÇÃO NO BRASIL}

No Brasil, o parentesco por consanguinidade, somada à legitimidade dos filhos atribuída exclusivamente para os concebidos na constância do casamento, tiveram grande importância desde as Ordenações Filipinas, promulgada em 1603, por Filipe I, rei de Portugal (AGUIAR, 2005), até a Constituição Federal de 1988 (GAMA, 2003). Neste contexto, Nelson Nery Junior e Rosa Maria de Andrade Nery (2013) asseveram que o Código 
Civil de 1916 privilegiava o vínculo de parentesco consanguíneo, depois, de afinidade e, por último, a adoção civil.

Para facilitar a compreensão do que foi dito, é interessante definir esses tipos de parentesco: parentesco consanguíneo, parentesco por afinidade e o parentesco civil ou adoção civil. 0 parentesco consanguíneo é aquele existente entre pessoas que mantêm entre si um vínculo biológico ou de sangue. 0 parentesco por afinidade é o existente entre um cônjuge e os parentes do outro cônjuge, ou entre o companheiro e os parentes do outro companheiro. Por último, o parentesco civil é aquele decorrente de outra origem, que não seja a consanguinidade ou a afinidade, por exemplo, a adoção (TARTUCE, 2015).

Entretanto, com os progressos científicos no conhecimento da vida humana e com a valorização dos vínculos afetivos, estão sendo reconhecidas outras formas de parentesco civil, quais sejam: o parentesco decorrente de técnicas de reprodução assistida e a parentalidade "socioafetiva".

Como visto, o Código Civil de 2002 previu a reprodução artificial homóloga e a heteróloga, em seu art. 1.597, que trata da presunção de filiação, e o Supremo Tribunal Federal, no julgamento da ADI n. 3.510, em 29 de maio de 2008, estabeleceu que a opção do casal por um processo de reprodução humana assistida é direito público subjetivo à liberdade ou à autonomia da vontade, previsto no preâmbulo da Constituição Federal e em seu art. 5으, bem como direito ao planejamento familiar, fundado nos princípios da dignidade da pessoa humana e da paternidade responsável.

Ademais, o Enunciado n. 339, da IV Jornada de Direito Civil, realizada em outubro de 2006, afirmou que "a paternidade socioafetiva, calcada na vontade livre, não pode ser rompida em detrimento do melhor interesse do filho". No mesmo sentido, o Enunciado n. 519, da V Jornada de Direito Civil, dispõe que "o reconhecimento judicial do vínculo de parentesco em virtude da socioafetividade deve ocorrer a partir da relação entre pai(s) e filho(s), com base na posse do estado de filho, para que produza os efeitos pessoais e patrimoniais".

O Provimento no 52, de 14 de março de 2016, da Corregedoria Nacional de Justiça, posicionou-se no sentido de que a paternidade/maternidade socioafetiva é tão importante ou até mais do que a biológica, como se infere a partir do artigo $2 \stackrel{\circ}{\circ}$. Embora exista a obrigatoriedade, para o 
ato de registro civil, da apresentação de documentos dos ascendentes biológicos, isto não garante o reconhecimento de vínculo de parentesco (paternidade-filiação). ${ }^{12}$ Os doadores, assim, não serão reconhecidos como tendo qualquer grau de parentesco com o infante (ASSUMPÇÃO; ASSUMPÇÃO, 2017, online).

Apesar disso, vale ressaltar que nem sempre os filhos foram tratados igualmente pelo sistema jurídico brasileiro. Guilherme Calmon Nogueira da Gama (2003) aponta que o Código Civil de 1916 dividia os filhos em: filhos legítimos, filhos legitimados e filhos ilegítimos, quanto a estes, existiam os filhos naturais e os filhos espúrios, que, respectivamente, significavam os adulterinos e os incestuosos (GAMA, 2003). Somente, a partir da Constituição Federal de 1998, no seu artigo 227, §6º que houve a proibição expressa da distinção entre os filhos: "Os filhos, havidos ou não da relação do casamento, ou por adoção, terão os mesmos direitos e qualificações, proibidas quaisquer designações discriminatórias relativas à filiação".

0 termo "filiação" procede do latim filiatio, que significa o laço de parentesco dos filhos com os pais, procedência, enlace. Quando a relação de parentesco é considerada em face do pai, chama-se paternidade, quando em face da mãe, denomina-se maternidade (LÔBO, 2011). Segundo Flávio Tartuce (2015, p. 370), "a filiação pode ser conceituada como sendo a relação jurídica decorrente do parentesco por consanguinidade ou outra origem, estabelecida particularmente entre os ascendentes e descendentes de primeiro grau".

Com efeito, os laços de parentesco dos filhos com os pais podem ocorrer de outras formas que não sejam pela consanguinidade. Neste diapasão, a doutrina civilista lista como fundamentos para a formação dos vínculos paternidade-filiação e maternidade-filiação: o biológico, o jurídico-legal e o "afeto" ou "solidariedade familiar" (PEREIRA JÚNIOR E OLIVEIRA NETO, 2016) ${ }^{13}$. A filiação biológica é aquela que decorrente do vínculo consanguíneo. A filiação jurídica é a filiação presumida em lei. E a filiação socioafetiva é o caso da pessoa ser vista socialmente como filho ou filha de determinado homem ou determinada mulher que biologicamente não é seu pai ou sua mãe, por exemplo, o marido ou o companheiro que se comporta como pai do filho da sua esposa ou companheira, e recebe reciprocamente tratamento "afetivo" dele (GAMA, 2003; LÔBO, 2011; 
NERY JÚNIOR, NERY, 2013; TARTUCE, 2015).

Por último, conclui-se que a filiação é uma relação jurídica, e como toda relação jurídica, ela constitui, modifica ou extingue direitos, pretensões, ações ou exceções (MIRANDA, 1983). Sendo assim, no próximo tópico, serão analisados: (1) a possibilidade jurídico do doador de material genético de ter reconhecida a filiação biológica; e (2) os efeitos jurídicos deste estado de filiação.

\section{RECONHECIMENTO DOS FILHOS E MULTIPARENTALIDADE}

O direito ao reconhecimento dos filhos está disciplinado no Código Civil de 2002. 0 Código Civil de 2002, em seu art. 1.607, estabelece que "o filho havido fora do casamento pode ser reconhecido pelos pais, conjunta ou separadamente". Não obstante, o art. 1.614, do Código Civil de 2002 condiciona o reconhecimento do filho maior ao seu consentimento, e prevê que, em caso de filho menor, este pode impugnar o reconhecimento, nos quatro anos que se seguirem à sua maioridade, ou à emancipação. Ademais, o reconhecimento voluntário de filho possui quatro vias: o registro de nascimento, a escritura pública ou escrito particular, o testamento e a manifestação direta e expressa perante o juiz (art. 1.609, CC/2002).

A partir dos dispositivos do Código Civil, os doutrinadores civilistas passaram a buscar uma definição para o instituto do "reconhecimento dos filhos". Paulo Luiz Netto Lôbo (2011, p. 255) define o reconhecimento dos filhos como um "ato jurídico em sentido estrito de caráter personalíssimo", porque apenas produz efeitos em relação aos próprios perfilhadores (mãe ou pai). No mesmo sentido, Flávio Tartuce (2015, p. 404) afirma que "o reconhecimento de filhos constitui um ato jurídico stricto sensu, ou em sentido estrito, justamente porque os seus efeitos são apenas aqueles decorrentes de lei".

Ressalte-se que o reconhecimento voluntário de filho apenas é possível quando este não houver sido registrado ou quando o registro de nascimento tiver sido feito somente em relação a um dos pais (LÔBO, 2011). Fora dessas hipóteses, ninguém pode reclamar estado contrário ao que consta no registro de nascimento, salvo provado erro ou falsidade, 
conforme o art. 1.604, do Código Civil.

Neste sentido, em 05 de novembro de 2006, o Superior Tribunal de Justiça, no julgamento do Recurso Especial no 709608/MS, cujo relator é o Ministro João Otávio de Noronha, decidiu, com base no art. 1.604 do CC/2002, que ninguém pode vindicar estado contrário ao que consta do registro de nascimento, salvo quando for perfeitamente demonstrado que houve vício de consentimento (erro, coação, dolo, fraude ou simulação) no momento da declaração de reconhecimento do filho, mediante escritura pública, pois, sabendo o pretenso pai de que o filho não é seu, mas movido pelo vínculo socioafetivo e sentimento de nobreza, sua vontade, aferida em condições normais de discernimento, está materializada e será mantida.

O Supremo Tribunal Federal, por outro lado, no julgamento do Recurso Extraordinário n. 898060/SC ${ }^{14}$, que ocorreu no dia 21 de setembro de 2016, e gerou o Informativo n. 840, criou a multiparentalidade (ou pluriparentalidade) no Brasil, ao decidir que a "paternidade socioafetiva, declarada ou não em registro público, não impede o reconhecimento do vínculo de filiação concomitante baseado na origem biológica, com os efeitos jurídicos próprios" (Informativo n. 840/STF). Curioso é o fundamento utilizado pela Suprema Corte para a criação deste instituto jurídico. Ela apoiou-se no "sobreprincípio" da dignidade da pessoa humana, na superação de óbices legais ao pleno desenvolvimento das famílias, no direito à busca da felicidade - princípio, segundo o STF, constitucional implícito -, na vedação à discriminação e hierarquização entre espécies de filiação (art. 227, § 6ํㅡ, CF/88) e no princípio da paternidade responsável.

No que se trata do reconhecimento dos filhos pelo doador de material genético, Pietro Perlingieri (2002, p. 177) assevera: "dúvidas surgem sobre a possibilidade de o doador reconhecer o nascido somente para fins patrimoniais e sucessórios, mas sempre deverá lhe ser atribuído o direito ao reconhecimento".

Por tudo considerado, se o ordenamento jurídico brasileiro - legislação, jurisprudência, costume, doutrina e/ou princípios gerais do Direito - vier a reconhecer a possibilidade do doador de material genético reconhecer a prole como seu filho ou filha, figurando como pai biológico na certidão de nascimento, ao lado ou não do pai socioafetivo, e da mãe, a paternidade biológica produziria os mesmos efeitos jurídicos da pater- 
nidade socioafetiva: dever de garantir ao filho a saúde, a alimentação, a educação, o lazer, a profissionalização, a cultura, a dignidade, o respeito, a liberdade e a convivência familiar e comunitária, conforme o caput, do art. 227, da Constituição Federal de 1988.

\section{CONCLUSÃO}

Indubitavelmente, verifica-se que as ciências médicas têm realizado progressos no conhecimento da vida humana, principalmente nas fases iniciais de sua existência, resultando, por conseguinte, na possibilidade de união artificial dos gametas feminino e masculino dentro ou fora do corpo da mulher, que darão origem a um novo ser humano. Porém, a união de componentes genéticos advindos de doador anônimo tem gerado problemas no âmbito jurídico, dentre os quais: o direito ao anonimato do doador violar o direito de identidade genética da pessoa, e o doador, após sair do anonimato e conhecer a pessoa gerada com seu material genético, buscar reconhecer, judicialmente, a filiação.

0 Conselho Federal de Medicina, através dos arts. $2^{\circ}$ e 4ํㅜㄴ, Seção 4, da Resolução no 2.121/2015, assegura o sigilo sobre a identidade civil dos doadores de material genético. A doutrina pátria diverge em relação a essa proteção do direito ao anonimato do doador de material genético. Os autores dividem-se em: (1) aqueles que criticam o anonimato do doador, porque viola o direito ao acesso à origem genética, social e cultural e, por conseguinte, fere o princípio da "dignidade da pessoa humana"; (2) aqueles que defendem o anonimato do doador, para evitar o direito à investigação de paternidade, à reivindicação de alimentos e de herança, supostamente indesejados pelo doador. A jurisprudência das Cortes brasileiras, por sua vez, vem protegendo e garantindo o direito de qualquer pessoa conhecer a sua origem genética, porque se trata de uma situação existencial. Finalmente, a Corregedoria Nacional de Justiça põe fim ao impasse entre o anonimato do doador e a identidade genética da pessoa concebida por reprodução assistida heteróloga, por meio do Provimento n⿳0 52, o qual determina o direito ao conhecimento da origem genética extrajudicialmente.

0 problema maior gira em torno de o doador conhecer os filhos biológicos e, posteriormente, requerer judicialmente o reconhecimento 
da filiação. 0 art. 1.604 do Código Civil de 2002 proíbe o reconhecimento de filho quando este já tiver sido registrado com dois vínculos, ou seja, na certidão de nascimento consta um pai e uma mãe, dois pais ou duas mães. Ocorre que o Supremo Tribunal Federal, no julgamento Recurso Extraordinário n. 898090, em setembro de 2016, criou a multiparentalidade, ao decidir que a paternidade socioafetiva não impede o reconhecimento do vínculo de filiação concomitante baseado na origem biológica.

Com efeito, conjectura-se que o Supremo Tribunal Federal afastou tacitamente o art. 1.604, do Código Civil de 2002. Porém, o direito ao reconhecimento dos filhos ainda passa por outro percalço, antes de ser concretizado, que é a autorização do filho, se for maior de idade, e em caso de filho menor, este pode impugnar o reconhecimento, nos quatro anos que se seguirem à sua maioridade, ou à emancipação (art. 1.614, CC/2002).

Conclui-se que o provimento no 52 da CNJ e a criação da multiparentalidade pelo Supremo Tribunal Federal gerou a possibilidade do doador do material genético requerer judicialmente o conhecimento da filiação e ter seu pedido atendido, desde que a paternidade e/ou maternidade biológica atenda ao princípio do melhor interesse da prole.

\section{NOTAS}

10 presente artigo é fruto de pesquisa realizada com apoio da Fundação Cearense de Apoio ao Desenvolvimento Científico e Tecnológico (FUNCAP), com bolsa de formação acadêmica na modalidade mestrado acadêmico - Edital no 56/2016 da Universidade de Fortaleza.

2 O Provimento no 52, da Corregedoria Nacional de Justiça, de 14 de março de 2016, está disponível no sítio eletrônico:<http://www.cnj.jus.br/files/conteudo/arquivo/2016/03/6bd953c109123 13a24633f1a1e6535e1.pdf>. Acesso em: 08 nov. 2017.

3 Ementa: Agravo Regimental no Recurso Especial. Ação Declaratória. Ofensa ao art. 557 do CPC. Inexistência. negativa de paternidade. Presunção pater is est. Ausência de erro ou coação no momento do registro. Paternidade socioafetiva configurada. Acórdão a quo em harmonia com a jurisprudência desta corte. Súmula 83/STJ. Agravo Regimental desprovido. 1. Em relação à apontada ofensa ao art. 557 do CPC, esta Corte tem jurisprudência firmada no sentido de que "(...) é possível ao Relator negar seguimento a recurso manifestamente inadmissível, improcedente ou prejudicado não ofendendo, assim, o princípio da colegialidade. Ademais, com a interposição do agravo regimental, fica superada a alegação de nulidade pela violação ao referido princípio, ante a devolução da matéria à apreciação pelo Órgão Julgador." (AgRg no REsp 1.113.982/PB, Relatora a Ministra Laurita Vaz, DJe de 29/8/2014).

4 CHOLODENKO, Lisa. Minhas mães e meu pai [Filme-vídeo]. Estados Unidos, 2010.

50 art. 226 da Constituição Federal de 1988 estabelece nos seus $\S \S 3^{\circ}$ e $4^{\circ}$, respectivamente, que "Para efeito da proteção do Estado, é reconhecida a união estável entre o homem e a mulher como entidade familiar, devendo a lei facilitar sua conversão em casamento" e "Entende-se, também, como entidade familiar a comunidade formada por qualquer dos pais e seus descendentes". 
6 Art. 226. § 7ํ Fundado nos princípios da dignidade da pessoa humana e da paternidade responsável, o planejamento familiar é livre decisão do casal, competindo ao Estado propiciar recursos educacionais e científicos para o exercício desse direito, vedada qualquer forma coercitiva por parte de instituições oficiais ou privadas.

7 Art. 1.607. O filho havido fora do casamento pode ser reconhecido pelos pais, conjunta ou separadamente.

8 Art. 1.609. 0 reconhecimento dos filhos havidos fora do casamento é irrevogável e será feito: [...] IV - por manifestação direta e expressa perante o juiz, ainda que o reconhecimento não haja sido o objeto único e principal do ato que o contém. [...]

9 Ementa: Recurso Extraordinário. Direito Processual Civil e Constitucional. Repercussão geral reconhecida. Ação de investigação de paternidade declarada extinta, com fundamento em coisa julgada, em razão da existência de anterior demanda em que não foi possível a realização de exame de DNA, por ser o autor beneficário da justiça gratuita e por não ter o estado providenciado a sua realização. Repropositura da ação. Possibilidade, em respeito à prevalência do direito fundamental à busca da identidade genética do ser, como emanação de seu direito de personalidade. 1. É dotada de repercussão geral a matéria atinente à possibilidade da repropositura de ação de investigação de paternidade, quando anterior demanda idêntica, entre as mesmas partes, foi julgada improcedente, por falta de provas, em razão da parte interessada não dispor de condições econômicas para realizar o exame de DNA e o Estado não ter custeado a produção dessa prova. 2. Deve ser relativizada a coisa julgada estabelecida em ações de investigação de paternidade em que não foi possível determinar-se a efetiva existência de vínculo genético a unir as partes, em decorrência da não realização do exame de DNA, meio de prova que pode fornecer segurança quase absoluta quanto à existência de tal vínculo. 3. Não devem ser impostos óbices de natureza processual ao exercício do direito fundamental à busca da identidade genética, como natural emanação do direito de personalidade de um ser, de forma a tornar-se igualmente efetivo o direito à igualdade entre os filhos, inclusive de qualificações, bem assim o princípio da paternidade responsável. 4. Hipótese em que não há disputa de paternidade de cunho biológico, em confronto com outra, de cunho afetivo. Busca-se o reconhecimento de paternidade com relação a pessoa identificada. 5. Recursos extraordinários conhecidos e providos. (RE 363889, Relator(a): Min. Dias Toffoli, Tribunal Pleno, julgado em 02/06/2011, Acórdão Eletrônico Repercussão Geral Mérito DJe-238 DIVULG 15-12-2011 PUBLIC 16-12-2011 RTJ VOL-00223-01 PP-00420)

100 entendimento do Supremo Tribunal Federal sobre a prevalência do direito à identidade genética sobre o anonimato tornou-se um precedente. Neste sentido, segue decisão no AR $1244 \mathrm{EI} /$ MG: Ementa: Embargos Infringentes na ação rescisória. Direito Civil e Constitucional. Ação de investigação de paternidade cumulada com petição de herança. Filho adulterino. Paternidade não contestada pelo marido. Direito de ter o filho reconhecido, a qualquer tempo, o seu pai biológico. Prevalência do direito fundamental à busca da identidade genética como direito de personalidade. Precedente. Embargos infringentes providos. (AR 1244 EI, Relator(a): Min. Cármen Lúcia, Tribunal Pleno, julgado em 22/09/2016, acórdão eletrônico DJE-063 Divulg 29-03-2017 Public 30-03-2017).

11 Ementa: Direito civil. Família. Recurso especial. Ação de investigação de paternidade e maternidade. Vínculo biológico. Vínculo sócio-afetivo. Peculiaridades. A “adoção à brasileira”, inserida no contexto de filiação sócio-afetiva, caracteriza-se pelo reconhecimento voluntário da maternidade/ paternidade, na qual, fugindo das exigências legais pertinentes ao procedimento de adoção, o casal (ou apenas um dos cônjuges/companheiros) simplesmente registra a criança como sua filha, sem as cautelas judiciais impostas pelo Estado, necessárias à proteção especial que deve recair sobre os interesses do menor. 0 reconhecimento do estado de filiação constitui direito personalíssimo, indisponível e imprescritível, que pode ser exercitado sem qualquer restrição, em face dos pais ou seus herdeiros. 0 princípio fundamental da dignidade da pessoa humana, estabelecido no art. 1ํㅡㄹ inc. III, da CF/88, como um dos fundamentos da República Federativa do Brasil, traz em seu bojo o direito à identidade biológica e pessoal. Caracteriza violação ao princípio da dignidade da pessoa humana cercear o direito de conhecimento da origem genética, respeitando-se, por conseguinte, a necessidade psicológica de se conhecer a verdade biológica. A investigante não pode ser penalizada pela conduta irrefletida dos pais biológicos, tampouco pela omissão dos pais registrais, apenas sanada, na hipótese, quando aquela já contava com 50 
anos de idade. Não se pode, portanto, corroborar a ilicitude perpetrada, tanto pelos pais que registraram a investigante, como pelos pais que a conceberam e não quiseram ou não puderam dar-lhe o alento e o amparo decorrentes dos laços de sangue conjugados aos de afeto. Dessa forma, conquanto tenha a investigante sido acolhida em lar "adotivo" e usufruído de uma relação sócio-afetiva, nada lhe retira o direito, em havendo sua insurgência ao tomar conhecimento de sua real história, de ter acesso à sua verdade biológica que lhe foi usurpada, desde o nascimento até a idade madura. Presente o dissenso, portanto, prevalecerá o direito ao reconhecimento do vínculo biológico. Nas questões em que presente a dissociação entre os vínculos familiares biológico e sócio-afetivo, nas quais seja o Poder Judiciário chamado a se posicionar, deve o julgador, ao decidir, atentar de forma acurada para as peculiaridades do processo, cujos desdobramentos devem pautar as decisões. Recurso especial provido. (REsp 833712/RS, Rel. Ministra Nancy Andrighi, Terceira Turma, julgado em 17/05/2007, DJ 04/06/2007, p. 347).

12 Art. $2^{\circ}$, $§ 1^{\circ}$ Nas hipóteses de doação voluntária de gametas ou de gestação por substituição, deverão ser apresentados: I- Termo de consentimento prévio, por instrumento público, do doador ou doadora, autorizando, expressamente, que o registro de nascimento da criança a ser concebida se dê em nome de outrem; II - Termo de aprovação prévia, por instrumento público, do doador ou doadora, autorizando, expressamente, a realização do procedimento de reprodução assistida; III - Termo de consentimento, por instrumento público, de cônjuge ou do companheiro da beneficiária ou receptora da reprodução assistida, autorizando expressamente a realização do procedimento.

13 Antonio Jorge Pereira Júnior e José Weidson de Oliveira Neto (2016) discordam do estudo dos afetos pelo Direito, principalmente, quando são associados ao pouco definido princípio da dignidade da pessoa humana, fortemente usado pela jurisprudência pátria na fundamentação das suas decisões. Os referidos autores explicam que os afetos estão encerrados em uma realidade individual subjetiva, fora do alcance do Direito, que compete o estudo de "condutas". Deste modo, o termo correto seria "solidariedade familiar" no lugar de "afeto".

14 Ementa: Recurso Extraordinário. Repercussão Geral reconhecida. Direito Civil e Constitucional. Conflito entre paternidades socioafetiva e biológica. Paradigma do casamento. Superação pela Constituição de 1988. Eixo central do Direito de Família: deslocamento para o plano constitucional. Sobreprincípio da dignidade humana (art. 1ํㅡㄹ III, da CRFB). Superação de óbices legais ao pleno desenvolvimento das famílias. Direito à busca da felicidade. Princípio constitucional implícito. Indivíduo como centro do ordenamento jurídico-político. Impossibilidade de redução das realidades familiares a modelos pré-concebidos. Atipicidade constitucional do conceito de entidades familiares. União estável ( $\operatorname{rrt.} 226, \S 3^{\circ}$, CRFB) e família monoparental ( $\operatorname{art.} 226$, § 4을 CRFB). Vedação à discriminação e hierarquização entre espécies de filiação (art. 227, § 6º, CRFB). Parentalidade presuntiva, biológica ou afetiva. Necessidade de tutela jurídica ampla. Multiplicidade de vínculos parentais. Reconhecimento concomitante. Possibilidade. Pluriparentalidade. Princípio da paternidade responsável (art. 226, § 7º, CRFB). Recurso a que se nega provimento. Fixação de tese para aplicação a casos semelhantes. 1 . 0 prequestionamento revela-se autorizado quando as instâncias inferiores abordam a matéria jurídica invocada no Recurso Extraordinário na fundamentação do julgado recorrido, tanto mais que a Súmula n. 279 desta Egrégia Corte indica que o apelo extremo deve ser apreciado à luz das assertivas fáticas estabelecidas na origem. 2 . A família, à luz dos preceitos constitucionais introduzidos pela Carta de 1988, apartou-se definitivamente da vetusta distinção entre filhos legítimos, legitimados e ilegítimos que informava o sistema do Código Civil de 1916, cujo paradigma em matéria de filiação, por adotar presunção baseada na centralidade do casamento, desconsiderava tanto o critério biológico quanto o afetivo. 3. A família, objeto do deslocamento do eixo central de seu regramento normativo para o plano constitucional, reclama a reformulação do tratamento jurídico dos vínculos parentais à luz do sobreprincípio da dignidade humana (art. 1으, III, da CRFB) e da busca da felicidade. 4. A dignidade humana compreende o ser humano como um ser intelectual e moral, capaz de determinar-se e desenvolver-se em liberdade, de modo que a eleição individual dos próprios objetivos de vida tem preferência absoluta em relação a eventuais formulações legais definidoras de modelos preconcebidos, destinados a resultados eleitos a priori pelo legislador. Jurisprudência do Tribunal Constitucional alemão (BVerfGE 45, 187). 5. A superação de óbices legais ao pleno desenvolvi- 
mento das famílias construídas pelas relações afetivas interpessoais dos próprios indivíduos é corolário do sobreprincípio da dignidade humana. 6.0 direito à busca da felicidade, implícito ao art. 1으, III, da Constituição, ao tempo que eleva o indivíduo à centralidade do ordenamento jurídico-político, reconhece as suas capacidades de autodeterminação, autossuficiência e liberdade de escolha dos próprios objetivos, proibindo que o governo se imiscua nos meios eleitos pelos cidadãos para a persecução das vontades particulares. Precedentes da Suprema Corte dos Estados Unidos da América e deste Egrégio Supremo Tribunal Federal: RE 477.554-AgR, Rel. Min. Celso de Mello, DJe de 26/08/2011; ADPF 132, Rel. Min. Ayres Britto, DJe de 14/10/2011. 7. 0 indivíduo jamais pode ser reduzido a mero instrumento de consecução das vontades dos governantes, por isso que o direito à busca da felicidade protege o ser humano em face de tentativas do Estado de enquadrar a sua realidade familiar em modelos pré-concebidos pela lei. 8. A Constituição de 1988, em caráter meramente exemplificativo, reconhece como legítimos modelos de família independentes do casamento, como a união estável (art. 226, § $3^{\circ}$ ) e a comunidade formada por qualquer dos pais e seus descendentes, cognominada "família monoparental" (art. 226, § $4^{\circ}$ ), além de enfatizar que espécies de filiação dissociadas do matrimônio entre os pais merecem equivalente tutela diante da lei, sendo vedada discriminação e, portanto, qualquer tipo de hierarquia entre elas (art. 227, § 6º). 9. As uniões estáveis homoafetivas, consideradas pela jurisprudência desta Corte como entidade familiar, conduziram à imperiosidade da interpretação não-reducionista do conceito de família como instituição que também se forma por vias distintas do casamento civil (ADI no. 4277, Relator(a): Min. AYRES BRITTO, Tribunal Pleno, julgado em 05/05/2011). 10. A compreensão jurídica cosmopolita das famílias exige a ampliação da tutela normativa a todas as formas pelas quais a parentalidade pode se manifestar, a saber: (i) pela presunção decorrente do casamento ou outras hipóteses legais, (ii) pela descendência biológica ou (iii) pela afetividade. 11. A evolução científica responsável pela popularização do exame de DNA conduziu ao reforço de importância do critério biológico, tanto para fins de filiação quanto para concretizar o direito fundamental à busca da identidade genética, como natural emanação do direito de personalidade de um ser. 12. A afetividade enquanto critério, por sua vez, gozava de aplicação por doutrina e jurisprudência desde o Código Civil de 1916 para evitar situações de extrema injustiça, reconhecendo-se a posse do estado de filho, e consequentemente o vínculo parental, em favor daquele utilizasse o nome da família (nominatio), fosse tratado como filho pelo pai (tractatio) e gozasse do reconhecimento da sua condição de descendente pela comunidade (reputatio). 13. A paternidade responsável, enunciada expressamente no art. 226, § 70 , da Constituição, na perspectiva da dignidade humana e da busca pela felicidade, impõe o acolhimento, no espectro legal, tanto dos vínculos de filiação construídos pela relação afetiva entre os envolvidos, quanto daqueles originados da ascendência biológica, sem que seja necessário decidir entre um ou outro vínculo quando o melhor interesse do descendente for o reconhecimento jurídico de ambos. 14. A pluriparentalidade, no Direito Comparado, pode ser exemplificada pelo conceito de "dupla paternidade" (dual paternity), construído pela Suprema Corte do Estado da Louisiana, EUA, desde a década de 1980 para atender, ao mesmo tempo, ao melhor interesse da criança e ao direito do genitor à declaração da paternidade. Doutrina. 15. Os arranjos familiares alheios à regulação estatal, por omissão, não podem restar ao desabrigo da proteção a situações de pluriparentalidade, por isso que merecem tutela jurídica concomitante, para todos os fins de direito, os vínculos parentais de origem afetiva e biológica, a fim de prover a mais completa e adequada tutela aos sujeitos envolvidos, ante os princípios constitucionais

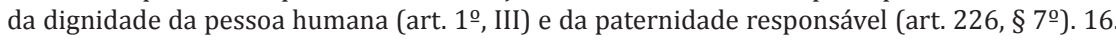
Recurso Extraordinário a que se nega provimento, fixando-se a seguinte tese jurídica para aplicação a casos semelhantes: "A paternidade socioafetiva, declarada ou não em registro público, não impede o reconhecimento do vínculo de filiação concomitante baseado na origem biológica, com os efeitos jurídicos próprios". (RE 898060, Relator(a): Min. Luiz Fux, Tribunal Pleno, julgado em 21/09/2016, Processo eletrônico DJe-187 DIVULG 23-08-2017 PUBLIC 24-08-2017). 


\section{REFERÊNCIAS}

AGUIAR, Mônica. Direito à filiação e bioética. Rio de Janeiro: Forense, 2005.

ALEXY, Robert. Teoria dos direitos fundamentais. Tradução de Virgílio Afonso da Silva. São Paulo: Malheiros, 2008.

ASSUMPÇÃO, Letícia Franco Maculan; ASSUMPÇÃO, Isabela Franco Maculan. Novas considerações sobre o provimento no 52/CNJ, que disciplinou o reconhecimento extrajudicial da filiação decorrente da reprodução assistida. IN: Associação dos Notários e Registradores do Brasil, Belo Horizonte-MG, 2017. Disponível em: <http://www.anoreg.org.br/index.php?option=com_content\& view=article \&id=28317:artigo-novas-consideracoes-sobre-o-provimento-n52-cnj-que-disciplinou-o-reconhecimento-extrajudicial-da-filiacao-decorrenteda-reproducao-assistida-por-leticia-franco-maculan-assumpcao-e-isabelafranco-maculan-assumpcao\&catid=64\&Itemid=184> . Acesso em: 08 nov. 2017.

BRASIL. Constituição (1988). Constituição da República Federativa do Brasil, Brasília, DF, Senado, 1988. Disponível em: <http://www.planalto.gov.br/ ccivil_03/constituicao/constituicaocompilado.htm>. Acesso em: 25 out. 2017.

CNJ. Provimento no 52, da Corregedoria Nacional de Justiça, de 14 de março de 2016. Disponível em: <http://www.cnj.jus.br/files/conteudo/ arquivo/2016/03/6bd953c10912313a24633f1a1e6535e1.pdf>. Acesso em: 09 nov. 2017.

. Enunciado n. 339, da IV Jornada de Direito Civil, última alteração em 18 de janeiro de 2016. Disponível em: <http://www.cjf.jus.br/enunciados/enunciado/369>. Acesso em: 13 nov. 2017.

Lei no 10.406, 10 de janeiro de 2002. Código civil. Disponível em: <http:// www.planalto.gov.br/ccivil_03/leis/2002/110406.htm>. Acesso em: 15 out. 2017.

. CFM. Resolução no 2.121, do Conselho Federal de Medicina, de 24 set. 2015. Disponível em: <http://www.portalmedico.org.br/resolucoes/ cfm/2015/2121_2015.pdf>. Acesso em: 13 nov. 2017.

Superior Tribunal de Justiça. Agravo Regimental no Recurso Especial no 1.113.982/PB. Relatora Min. Laurita Vaz, Quinta Turma, julgado em 
19/08/2014. Disponível em: <https://ww2.stj.jus.br/processo/revista/documento $/$ mediado $/$ ?componente $=I T A \&$ sequencial $=1340763 \&$ num_registro $=2$ 00900425310\&data $=20140829 \&$ formato $=$ HTML $>$ Acesso em: 29 out. 2017.

BRASIL. Superior Tribunal de Justiça. Recurso Especial no 833712. Relatora Min. Nancy Andrighi, Terceira Turma, julgado em 17/05/2007. Disponível em: $<$ http://www.stj.jus.br/SCON/jurisprudencia/toc.jsp?processo=833712\&\&b= ACOR\&thesaurus=JURIDICO\&p=true >. Acesso em: 13 nov. 2017.

. Superior Tribunal de Justiça. Recurso Especial no 709.608/ MS. Rel. Ministro João Otávio de Noronha, Quarta Turma, julgado em 05/11/2009. Disponível em: <https://ww2.stj.jus.br/processo/revista/ inteiroteor $/$ ?num_registro $=200401746167 \& d t$ publicacao $=23 / 11 / 2009 \mathrm{P}$. Acesso em: 13 nov. 2017.

. Supremo Tribunal Federal. Recurso Extraordinário no 363889/DF. Relator Min. Dias Toffoli, Tribunal Pleno, julgado em 02/06/2011. Disponível em: <http://www.stf.jus.br/portal/jurisprudencia/listarJurisprudencia.asp?s1 $=\% 28363889 \% 2 \mathrm{ENUME} \% 2 \mathrm{E}+\mathrm{OU}+363889 \% 2 \mathrm{EACMS} \% 2 \mathrm{E} \% 29 \&$ base=baseAco rdaos\&url=http://tinyurl.com/glm73lh>. Acesso em: 13 nov. 2017.

. Supremo Tribunal Federal. Recurso Extraordinário no 898060/SC. Relator Min. Luiz Fux, Tribunal Pleno, julgado em 21/09/2016. Disponível em: <http:// redir.stf.jus.br/paginadorpub/paginador.jsp?docTP=TP\&docID=13431919>. Acesso em: 13 nov. 2017.

BUSTAMANTE, Thomas. Princípios, regras e conflitos normativos: um modelo para a justificação das decisões contra legem a partir da teoria jurídica de Robert Alexy. Pensar, Fortaleza, v. 15, n. 2, p. 603-628, jul./dez. 2010. Disponível em: <http://ojs.unifor.br/index.php/rpen/article/view/2143/1743>. Acesso em: 09 nov. 2017.

CHAVES, Antônio. Direito à vida e ao próprio corpo. 2. ed. São Pulo: RT, 1994.

DINIZ, Maria Helena. O estado atual do biodireito. 3. ed. São Paulo: Saraiva, 2006.

GAMA, Guilherme Calmon Nogueira da. A Nova filiação: O Biodireito e as Relações Parentais: 0 Estabelecimento da Parentalidade-Filiação e os Efeitos Jurídicos da Reprodução Assistida Heteróloga. Rio de Janeiro: Renovar, 2003. 
LÔBO, Paulo Luiz Netto. Famílias. 4. ed. São Paulo: Saraiva, 2011.

LOUREIRO, Claudia Regina Magalhães. Introdução ao biodireito. São Paulo: Saraiva, 2009.

MIRANDA, Pontes de. Tratado de direito privado: Parte Geral. 4. ed. São Paulo: Revista dos Tribunais, 1983, t. 3.

MORAES, Maria Celina Bodin, Maria Celina Bodin. A caminho de um direito civil-constitucional. In: MORAES, Maria Celina Bodin. Na medida da pessoa humana: estudos de direito civil-constitucional. Rio de Janeiro: Renovar, 2010.

NAVES, Bruno Torquato de Oliveira; SÁ, Maria de Fátima Freire de. Manual de biodireito. Belo Horizonte: Del Rey, 2009.

NERY JÚNIOR, Nelson; NERY, Rosa Maria de Andrade. Código Civil: comentado. 10. ed. São Paulo: Revista dos Tribunais, 2013.

OLMOS, Paulo Eduardo. Quando a cegonha não vem: os recursos da medicina moderna para vencer a infertilidade. São Paulo: Carrenho, 2003.

PEREIRA JÚNIOR, Antonio Jorge; OLIVEIRA NETO, José Weidson de. (In)viabilidade do princípio da afetividade. Universitas JUS, v. 27, n. 2, p. 113-125, 2016. Disponível em: <https://www.publicacoesacademicas.uniceub.br/jus/article/ view/4170/3258 >. Acesso em: 13 nov. 2017.

PERLINGIERI, Pietro. Perfis do direito civil: Introdução ao Direito Civil Constitucional. 3. ed. Rio de Janeiro: Renovar, 2002.

SOUZA, Marise Cunha de. As Técnicas de Reprodução Assistida. A Barriga de Aluguel. A Definição da Maternidade e da Paternidade. Bioética. Revista da EMERJ, v. 13, no 50, 2010. Disponível em: <http://www.emerj.tjrj.jus.br/revistaemerj_online/edicoes/revista50/Revista50_348.pdf>. Acesso em: 08 dez. 2016.

TARTUCE, Flávio. Direito civil: Direito de Família. 10. ed. São Paulo: Método, 2015.

TEPEDINO, Gustavo. Temas de direito civil. Tomo 3. Rio de Janeiro: Renovar, 2009.

ZAGREBELSKY, Gustavo. El derecho dúctil. 10. ed. Madrid: Editorial Trota, 2011. 
Recebido em: 13-11-2017

Aprovado em: 26-1-2018

\section{Mariane Paiva Norões}

Mestranda do Programa de Pós-Graduação em Direito Constitucional da Universidade de Fortaleza (PPGD-UNIFOR). Especialista em Direito Civil (Anhanguera). Pesquisadora-bolsista da Fundação Cearense de Apoio ao Desenvolvimento Científico e Tecnológico (FUNCAP). Advogada.

E-mail: marianenoroes@hotmail.com

Universidade de Fortaleza - UNIFOR - Av. Washington Soares, 1321 - Bairro Edson - Fortaleza - CE.

\section{Antonio Jorge Pereira Júnior}

Doutor, Mestre e Bacharel em Direito pela Universidade de São Paulo (USP). Professor do Programa de Mestrado e Doutorado em Direito Constitucional da Universidade de Fortaleza (PPGD-UNIFOR).

E-mail: antoniojorge2000@gmail.com

Universidade de Fortaleza - UNIFOR - Av. Washington Soares, 1321 - Bairro Edson - Fortaleza - CE.

\section{Jéssica Ramos Saboia}

Mestranda em Direito Constitucional pelo Programa de Pos Graduação em Direito Constitucional da Universidade de Fortaleza (PPGD-UNIFOR). Membro do Laboratório de Ciências Criminais (LACRIM) da UNIFOR.

E-mail: jessicarsaboia@gmail.com

Universidade de Fortaleza - UNIFOR Av. Washington Soares, 1321 - Bairro Edson - Fortaleza - CE. 